\title{
Pastoral care in the healing of moral injury: A case of the Zimbabwe National Liberation War Veterans
}

\begin{tabular}{|c|c|}
\hline \multicolumn{2}{|c|}{$\begin{array}{l}\text { Author: } \\
\text { Herbert Moyo }\end{array}$} \\
\hline $\begin{array}{l}\text { Affiliation: } \\
{ }^{1} \text { School of Rel } \\
\text { Philosophy an } \\
\text { University of } \\
\text { South Africa }\end{array}$ & $\begin{array}{l}\text { igion, } \\
\text { d Classics, } \\
\text { kwaZulu-Natal, }\end{array}$ \\
\hline $\begin{array}{l}\text { Note: } \\
\text { This article is } \\
\text { section Practi } \\
\text { the Society fo } \\
\text { Theology in S }\end{array}$ & $\begin{array}{l}\text { oublished in the } \\
\text { cal Theology of } \\
\text { Practical } \\
\text { Duth Africa. }\end{array}$ \\
\hline $\begin{array}{l}\text { Corresponden } \\
\text { Herbert Moyo }\end{array}$ & ce to: \\
\hline $\begin{array}{l}\text { Email: } \\
\text { moyoh@ukzn }\end{array}$ & ac.za \\
\hline $\begin{array}{l}\text { Postal addres } \\
\text { School of Relig } \\
\text { Philosophy an } \\
\text { University of } \\
\text { Natal, P/B X01 } \\
\text { Pietermaritzb } \\
\text { South Africa }\end{array}$ & $\begin{array}{l}\text { s: } \\
\text { gion, } \\
\text { d Classics, } \\
\text { kwaZulu- } \\
\text { Scottsville, } \\
\text { urg 3201, }\end{array}$ \\
\hline $\begin{array}{l}\text { Dates: } \\
\text { Received: } 24 \mathrm{~F} \\
\text { Accepted: } 02 \\
\text { Published: } 25\end{array}$ & $\begin{array}{l}\text { eb. } 2015 \\
\text { Oct. } 2015 \\
\text { Nov. } 2015\end{array}$ \\
\hline $\begin{array}{l}\text { How to cite th } \\
\text { Moyo, H., } 201 \\
\text { in the healing } \\
\text { A case of the } \\
\text { National Liber } \\
\text { Veterans', HTS } \\
\text { Studies/Theol } \\
71(2), \text { Art. \#2S } \\
\text { http://dx.doi. } \\
\text { hts.v71i2.291 }\end{array}$ & $\begin{array}{l}\text { is article: } \\
5 \text {, 'Pastoral care } \\
\text { of moral injury: } \\
\text { Zimbabwe } \\
\text { ation War } \\
\text { Teologiese } \\
\text { ogical Studies } \\
19,11 \text { pages. } \\
\text { org/10.4102/ }\end{array}$ \\
\hline $\begin{array}{l}\text { Copyright: } \\
\text { C) 2015. The A } \\
\text { Licensee: AOS } \\
\text { OpenJournals. } \\
\text { licensed unde } \\
\text { Commons Attr } \\
\text { License. }\end{array}$ & $\begin{array}{l}\text { Authors. } \\
\text { IS } \\
\text { This work is } \\
r \text { the Creative } \\
\text { ribution }\end{array}$ \\
\hline 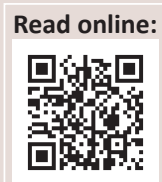 & $\begin{array}{l}\text { Scan this QR } \\
\text { code with your } \\
\text { smart phone or } \\
\text { mobile device } \\
\text { to read online. }\end{array}$ \\
\hline
\end{tabular}

This article is in the field of Practical theology with specific reference to pastoral care. The article is motivated by the growing number of conversions of members of the Zimbabwe National Liberation War Veterans Association (ex-combatants/war veterans), through miracle and spiritual healing Ministries under the leadership of Prophets. This article exposes the challenge of injured morals as a result of traumatic war experiences of ex-combatants during the war of liberation from colonialism in Zimbabwe. The violent acts in the political arena in Zimbabwe are linked to the military behaviour of the ex-combatants. This article also makes a critical analysis of the therapeutic narratives from ex-combatants, to conclude that violence in Zimbabwe is highly related to the injured morals of the ex-combatants. The war veterans are finding healing of moral injury from the miracles and exorcisms performed by Prophets.

\section{Introduction}

In Zimbabwe there is a problem with political violence, especially around election times (Blair 2002:116-120; Hill 2003:86; Makumbe 2003:4). This article links the political violence to the injured morals of the Zimbabwe National Liberation War Veterans (ex-combatants/war veterans) which need healing (Makumbe 2003:4). The focal point of this article is the repair and healing of these injured morals through pastoral care, as experienced by war veterans who are members of Ministries run by Prophets. Through empirical qualitative narrative research this paper discusses the pastoral care needs of ex-combatants, and exposes the pastoral healing Ministry of the Prophets who lead these Ministries.

In February 2002 the first church called a 'Ministry' specialising in healing and led by a Prophet was established in the Mberengwa district (Moyo 2014:127). The term 'Ministry' is used in place of the word 'church' whilst the title 'Prophet' is used in place of the title 'pastor' or 'reverend.' The same Ministry has established branches across the Mberengwa district and in the neighbouring Gwanda district, mainly in rural areas. Currently there are 46 branches (congregations) and 34 Prophets in Mberengwa and Gwanda. The Prophets' Ministries are active in pastoral care in the form of performing miracles for healing and the exorcism of evil spirits and demons (Shoko 2007:52). The Ministries are continuously uniquely attractive to war veterans (during the war they were popularly known as guerrillas). It should be noted that in Mberengwa and elsewhere in Zimbabwe the majority of war veterans are against the church ${ }^{1}$ as they associate it with colonialism (Bhebe 1999; Independent Catholic News 1988:6; Lan 1985; Tungamirai 1995:39), except those who remained as Christians during their guerrilla war experiences such as Canaan Banana, Ndabaningi Sithole and Bishop Abel Muzorewa (Banana 1989; Kriger 1995). The influx of war veterans to a particular church motivated me to undertake research on the relationship between the Prophets' Ministries and the war veterans. During the liberation war guerrillas subscribed to protection by their ancestors as well as the national spirit mediums of Mbuya Nehanda and Sekuru Chaminuka (Chung 2006; Lan 1985; Martin 1981; Murungu 2004; Ranger 1992; Shoko 2006). However, with the advent of Ministries in Mberengwa and Gwanda war veterans are inviting each other to the Ministries run by Prophets. This research has discovered that a few war veterans in the Mberengwa and Gwanda districts, who had joined some other churches prior to the advent of Prophets, have since transferred their membership to the Ministries. The question is: What is it that attracts war veterans in the Mberengwa and Gwanda districts to the Ministries? This article will attempt to answer this question through an analysis of the narratives of the ex-combatants.

In an informal discussion in the Mberengwa district, on 08 January 2009, Fuya Dlamini², a war veteran, who had joined the church Ministry in September 2008, explained the following:

\footnotetext{
1.This is so, especially with the mainline churches whose ministers in the colonial era had a significant presence of whites

2.The names of all the participants are false names as this article maintains the anonymity of participants. Specific geographic names (except the name of the district, province and country), are also avoided to preserve anonymity of the participants. The study does
} have ethical clearance from the University of KwaZulu-Natal. 
'The prophet managed to exorcise the spirit of a person that I killed during the war that has been haunting me since 1969. Following the healing by the prophet I no longer itch for human blood, I now have found rest and peace from this edge for war and violence. Because of the healing that I have received I have invited some of my colleagues who are also haunted by the same spirits to get help from the Prophet.'

Firstly, this informal discussion motivated me to discover the pastoral needs of war veterans which linked them to the Prophets. This exposes the fact that war veterans need healing from moral injury. Secondly, the research exposes the healing aspects of the pastoral care of Ministry of the Prophets that are attractive to war veterans. This article is of the view that the Ministries are offering healing to the war veterans who are longing for the healing of injured morals. Makumbe (2003:4) and Bhebe (1999) are of the view that war veterans have not been afforded the repair of injured morals and emotional demobilisation after obtaining political independence from colonial rule following a bloody guerrilla war. The key questions are:

- What are the pastoral care needs of the war veterans?

- What is it that is attracting war veterans to the Ministries of Prophets?

- Do the Prophets' Ministries offer healing to the war veterans' injured morals?

- How is pastoral care by the Prophets responding to the injured morals?

As noted earlier on, this article discusses the repair and healing of injured morals through pastoral care by Prophets.

The article links violent acts in the politics of Zimbabwe to the military behaviour of ex-combatants whose injured morals have not been healed. Hove and Mutanda (2014:125) argue that

[d]iscontented demobilised soldiers pose a serious threat to the country's security system if they are not meticulously handled. Most war veterans found it difficult to reintegrate into civilian life because the government did not have a devoted and authentic policy to put in place sustainable strategies which would integrate them into civilian life. (see also Chitiyo 2000; Kingma 2000; Kriger 2003:208; Tshuma 2006)

The article utilises in-depth interviews with ex-combatants and literature on moral injury - especially the work of Rita Nakashima Brock and Gabriela Lettini, entitled Soul repair: Recovering from moral injury after war (2012). ${ }^{3}$ The basic assumption is that War veterans have injured morals and that they associate their life challenges with evil spirits and spirits of people whom they killed during the war. War veterans are burdened by deep-seated memories of traumatic experiences of war in which they violated some of their profound moral foundations. About this, Shira and Litz

3.I have chosen this book because it deals with the same concept of moral injury However, the book is written from an American perspective and the authors are However, the book is written from an American perspective and the authors are
using psychology as a response to moral injury whilst I seek to discuss the use of religion, particularly pastoral care, as a response to moral injury.
(2012:1-2) identify that war is a core source of moral injury amongst combatants.

This article concludes that Prophets in Ministries are providing a pastoral healing service which other denominations are not offering, hence the influx of war veterans to the Ministries. The Prophet, whilst full of the Holy Spirit, listens to the narratives of the war veterans, anoints the war veterans with holy oil, exorcises the evil spirits and spirits of the dead following them and pronounces absolution to take away the self-guilt of anyone in the name of Jesus Christ.

\section{Defining some key terms used in this article Morals}

In this articlemoralsareviewed as a set of acceptablebehavioural patterns in a given community. Morals are normative values from both a cultural and religious perspective which are used as a measure for personal self-worth (Bernard 2005; Wallace \& Walker 1970). Morals determine self-acceptance, communal acceptance and cultural-religious validation. Moral injury occurs when one's experiences take away acceptable moral understanding from an individual to the point of changed behavioural patterns that go against what the individual might have viewed as moral before such experiences. Jonathan Shay (2010) explains this:

Moral injury is the damage done to one's conscience or moral compass when that person perpetrates, witnesses, or fails to prevent acts that transgress their own moral and ethical values or codes of conduct. (p. 16)

\section{Moral injury}

According to Shira and Litz (2012), moral injury comes as a consequence of the violation of one's deeply held moral standards by the self or by significant others:

Sometimes sufferers have committed an act that violates their moral principles, such as a killing. Sometimes it is a failure to act, such as failure to stop an insurgent who went on to kill a fellow soldier. It is marked by feelings of shame, guilt, and self-blame. (Shira \& Litz 2012:1-2)

In most cases victims of moral injury usually manifest selfdestructive behaviours such as drug abuse, being anti-social, careless about life, and in severe cases victims become suicidal (Amadiume \& An-Na'im 2000; Shira \& Litz 2012:1-2).

\section{Moral repair and moral healing}

Moral repair or healing of moral injury is when the victim is helped to cope with their experiences that would otherwise result in moral injury. The ideal is the restoration of the moral behaviour of a victim of moral injury to a moral state equivalent to that before the moral injury. Alternatively, if moral injury is based on self-guilt, then absolution and being accepted by the community can result in healing. Healing is not always a physical transformation, it can be psycho- 
spiritual. Such healing utilises rituals that engage the images, symbols and moral crisis points of an individual (Gerkin 1984:6; Louw 1995). Healing in this article is also understood as viewing the self positively, after having managed to cope with self-guilt and low self-esteem, thereby creating a sense of wholeness in the person. Louw (2013) says:

\begin{abstract}
In pastoral care we need to start speaking of 'human wholeness'. The reason for this is that health in a biblical sense points to life and salvation (the verb sozo, to save). In a comprehensive approach to health the use of the term spiritual healing could perhaps be too narrow. One might even speak of 'faith healing', 'divine healing', 'miraculous healing' or 'charismatic healing.' However, the reference to spiritual healing refers to wholeness and a comprehensive understanding of the concept of the soul, nephesh, which includes embodied life as experienced within the presence of God, as well as within a cultural system and network of social human relationships. (p. 2)
\end{abstract}

\section{Pastoral care}

I see pastoral care as acts of concern, empathy, compassion, kindness and love by the church, in most cases being represented by pastors, to people in unfortunate situations such as sickness, being affected by the spirit world and grieving following the loss of a significant other. According to this article pastoral care is the response by the church to human needs such as suffering and lack of wholeness, of which moral injury is an example. People with traumatic pathological spiritual, psychological and moral wounds, resulting from war atrocities, need pastoral care for healing and sustenance. Pastoral care is 'One of the sub-disciplines of practical theology, which in the past was referred to as shepherding, poimenics and soul care (Seelsorge)' (Buffel 2004:41; Van der Ven 1993:37). According to Lester (1995:1) 'Pastoral care and counselling are historically concerned with healing, guiding, sustaining, (reconciling) and liberating.' In fact, according to Moyo (2014):

$[P]$ astoral care is the ministry of the church in a given context which seeks to shepherd and empower church members, in particular, and the community in general, within the realities of that community. The aim of pastoral care is to enable growth and wellbeing of individuals and society at large. (p. 126)

An indispensable aspect of pastoral care by the church is pastoral counselling (Moyo 2014:126-127). Ward (2001) emphasises that it is difficult to think of a single definition of counselling because definitions depend on theoretical orientation. Msomi (2008) is of the view that counselling can only be meaningful if it is rooted in the cultural worldview of the client. Msomi (2008) further argues that counselling is a transformational learning-oriented process, which occurs in an interactive encounter between a counsellor and a counselee, aimed at reintegrating a client to cope with their reality. Thus, counselling equips people with coping mechanisms.

\section{Research methodology}

This article is the result of qualitative narrative research that utilised in-depth narrative interviews. The article also used literature reviews on studies that have been undertaken on war veterans in pastoral care, especially in the context of Zimbabwe where war veterans are actively involved in political developments. The literature is used in conjunction with empirical qualitative narrative research with indepth interviews of participants selected through snowball sampling as shown below.

\section{Qualitative narrative research with in-depth interviews}

I used a qualitative research paradigm as a way of enabling participants to share their narratives. The interviews were conducted in different settings that suited each participant's needs. The interviews took place between February 2009 and December 2013. I used the following open ended guiding questions to direct the discussions:

- Did you experience any traumatic events that are difficult to forget - if so, describe some of your experiences and feelings?

- How are you able to continue with your life with such guilt feelings and haunting traumatic experiences of war?

- What are your experiences of the following events in Zimbabwe: Gukurahundi, Murambatsvina, land reform and post-election disturbances in 2008?

- How are Prophets in your church helping you with your war experiences and related feelings?

\section{Sampling}

I used purposive sampling which was coupled with snowballing (Cohen \& Manion 1994:89). Purposive sampling was the ideal sampling style, as I had a specific closed target group (Salganik \& Heckathorn 2004:200). The research targeted war veterans (ex-combatants of the war of liberation in Zimbabwe). I initially approached two war veterans from my village whom I could interview. The two introduced me to other war veterans in the Mberengwa and Gwanda districts. The referrals by war veterans resulted in snowball sampling (chain referral sampling). In snowball sampling, which is a form of purposive sampling (Browne 2005:7), the war veterans whom I had contacted used their networks to refer me to other war veterans who could potentially participate in or contribute to the study. The size of the sample population was determined on the basis of theoretical saturation, which is the point in data collection when new data no longer brings additional insights in response to the research questions (Salganik \& Heckathorn 2004:214). The Zimbabwean war veterans are a politicised group, which makes it very difficult to interview them without politically related suspicions (Alden 2002:351; Chitiyo 2004:57-60; Gonda 2013; Kriger 2003; McGregor \& Jocelyn 2004:402). With referral to potential participants by other war veterans, this enabled the participants to trust me. The snowballing enabled me to access 44 ex-combatants before reaching saturation point. I continued to interview another 7 war veterans, but the information I received was the same as what I had gathered from the first 44 participants. Thus, I stopped the interviews after interviewing 51 war veterans. In origin, 22 research participants come from the Mberengwa district 
in the Midlands province of Zimbabwe whilst 29 come from the Gwanda district in the Matabeleland South Province.

I have made summaries of their responses to avoid any direct identification of individuals. In some instances participants gave responses that are a summary of the feelings of other participants. In such instances I have made direct quotations of these summary responses. In all situations I have maintained confidentiality to protect the identity of my interviewees.

\section{Failure to demobilise ex-combatants of the various wars in Zimbabwe}

Zimbabwe had been in war from the 1960s against the colonial government. The war of liberation was characterised by guerrilla warfare, with blacks fighting for liberation from colonial rule (Bhebe \& Ranger 1996; Johnson \& Martin 1981; Kriger 2003; McGregor \& Jocelyn 2004; Moorcraft \& McLaughlin 1981; Preston 2004). The major black people's movements were the Zimbabwe African National Liberation Army (ZANLA) and the Zimbabwe People's Revolutionary Army (ZIPRA), which were forces that fought in the armed struggle until independence in 1980 (Makumbe 2003:6). The veterans of this protracted war have not undergone psychoreligious counselling and rituals to deal with traumatic war experiences. In addition to the ex-combatants, there are also the Rhodesian Front forces that were defending the colonial government. The forces from these three military establishments were simply released from their duties into civilian life (Braganca \& Wallerstein 1982:12-13). There was no effort from the government or from NGOs to demilitarise the former soldiers to enhance their civilian life. Studies have constantly shown that the ex-combatants have failed to reintegrate into civilian life (Alexander \& Tendi 2008; Bernard 2005; Bhebe and Ranger 2001; Blair 2002:30, 116-120; Braganca \& Wallerstein 1982:12-13; Chitiyo 2000; Gonda 2013; Hill 2003:86; Martin 1981). To complicate this, Makumbe (2003) argues that,

on entering the corridors of power, the former liberation movement (ZANU-PF) failed to transform itself into a democratic political party. The guerrillas have still not taken off their uniforms; they have not yet laid down their guns. (p. 4)

Following Makumbe's (2003) observation it can be concluded that there has been no intentional national psychological, emotional, moral or mental demobilisation of guerrillas by the government of Zimbabwe. Related to this lack of ritualbased demobilisation, the problem is that the majority of the ex-combatants have no meaningful life (Makumbe 2003:6). Makumbe (2003:6) postulates that some of the ex-combatants show signs of mental disturbances, some are very violent and in fact politicians have used them in subsequent violent activities mainly around election times, as will be shown later. Civilian victims, who experienced the same war, are also forgotten; people who witnessed such things as bombings, torture and rape have not been healed from their traumatic experiences. The ex-combatants remain in war mode and any opportunity to put their inherent violent practices into action is taken with open hands (Braganca \& Wallerstein 1982:1213; Makumbe 2003:6).

Subsequent violent episodes in the political developments in Zimbabwe seem to be a viable means of releasing internal trauma. In a way violence directs the veterans into the mode of war, to which they are accustomed. In fact, as the excombatants have not been emotionally and psychologically demobilised, as stated earlier on, each opportunity to regroup and act in a style of war is grasped enthusiastically because it takes them back to the original context of war.

\section{Violent episodes and the role of war veterans in Zimbabwe}

Following political independence from colonialism, the government of Zimbabwe instituted violence that resulted in a genocide against its own citizens. The Gukurahundi was conducted from 1982 to 1987 by ex-combatants who are in commanding positions of the Zimbabwe National Army, together with Korean trained soldiers that were deployed in Matabeleland and the Midlands provinces (Catholic Commission for Justice and Peace and The Legal Resources Foundation [CCJP] 1997). They killed an estimated 20000 people (Jocelyn \& Joan 1999). Some were maimed whilst some were raped or sodomised and tortured (Zimbabwe Human Rights Association 1982:1). Brutal ways of killing were used such as dragging people behind a car, cutting open the wombs of pregnant women because they were said to be carrying dissidents, chopping off people's heads, throwing people into disused mine shafts, burying living people and closing people inside a house then burning it down (CCJP 1997). All this took place in full view of the victim's friends and family. At times those in the vicinity of these atrocities were forced to sing or applaud the actions of the soldiers. Failure to do so resulted in torture or death. The Gukurahundi commanders were former ZANLA combatants (Hill 2003:86). One could interpret that they sanctioned such brutality because of their injured morals. The Gukurahundi soldiers have yet to receive trauma counselling and ritual cleansing for killing innocent people. Blair (2002:30) notes, 'The result of the Gukurahundi haunts Zimbabwe to this day.'

War veterans participated in violent election campaigns for ZANU-PF in 2000, 2002 and 2005, up until the heavily militarised 2008 elections (Alexander \& Tendi 2008; Masunungure \& Bratton 2008). War veterans have been used in the 'delimitation of voter registration, voter education, campaigning, [and] manning command centers during the contested election' (The Zimbabwean 16 June 2011:4). This, according to Masunungure and Bratton (2008) and Felsman (2005), was central to vote rigging and voter intimidation, culminating in physical and psychological violence on the part of the electorate. War veterans have revived their war mode or soothed their injured morals by continuing violence to the benefit of ZANU-PF (Chitiyo 2000; Gonda 2013). 
In 2000 the war veterans were instrumental in the violent farm invasions where they re-enacted the liberation war and the Gukurahundi forms of violence (Alexander \& Tendi 2008; Blair 2002:116-120; Hill 2003:86). War veterans have become a tool for violent activities without any attempt to help them to repair their injured morals for reintegration into civilian life.

War veterans also participated in all the dehumanising operations carried out by the government against perceived enemies of ZANU-PF such as operation Murambatsvina [clean up] in May 2005 and operation Makavhoterapapi [whom did you vote for] in 2008 (Human Rights Watch 2008:16; Zimbabwe Institute report 2008), these being enacted in the name of the state (Bhebe \& Ranger 2003). The level of intimidation, torture and murder matched Gukurahundi events (Felsman 2005; Masunungure \& Bratton 2008) and gave war veterans an opportunity to return to full scale war mode, thereby soothing their injured morals.

\section{Research findings: Excerpts from interviews with ex-combatants in Zimbabwe}

Did you experience any traumatic events that are difficult to forget - if so, describe some of your experiences?

In response to the first question all the interviewees described their war experiences as traumatic and some events as difficult to forget. All the interviewees believe that they have been betrayed by their leaders because they have not been formally cleansed, hence they are haunted by the spirits of the dead. Of the interviewees, 48 of the 51 believe that they are being haunted by the spirits of the people whom they killed during the war. The worst time is when one tries to fall asleep; the haunting spirits replay the traumatic experiences in the form of nightmares, resulting in difficulties in falling asleep.

Firstly, eleven of the interviewees said that the haunting spirits can be soothed by taking alcohol and drugs. The spirits seem unable to attack a person under the influence of drugs. Secondly, the veterans argue that participating in violent episodes soothes their bitter injured morals that are always bedevilled by traumatic memories. So participating in violence of any magnitude gives the ex-combatants an opportunity to pacify the haunting spirits.

According to 37 interviewees, the most devastating experiences are killing someone using a knife, or stoning or strangling. The easiest way of killing was the use of the gun, where one could kill a person without looking directly at their eyes. This challenge is demonstrated by narratives from some of the interviewees. According to Sibanda:

'[T] he most difficult challenge was to kill a colleague believed to be a sell-out to the enemy. You see killing someone that you know and using other means other than the gun was traumatising but you could not do otherwise as long as you are commanded to do so. Their faces and pleadings live with you forever.' (Interview 15 June 2009)

\section{Miss Silibaziso says:}

'Going to train in Mozambique as a woman was a serious challenge. All the men in our camp did not see females as soldiers, they treated us as sex workers to entertain male counter parts. We were raped many times. And nobody saw this as crime against women. This image of being a sex object is refusing to go away, each time I look at any military male the image of being raped many times becomes alive in my mind. The time when the Rhodesian front attacked Nyadzonya in Mozambique was very traumatising. There were dead bodies strewn all over the place, men, women and children covered in blood and dust. We were not able to defend our colleagues, this was and is still devastating.' (Interview 06 September 2010)

Another traumatic narrative came from Comrade Mbizo who said:

\begin{abstract}
'The most traumatic incident that happened to me was when we were ambushed by the enemy. They brutally killed all the 17 members of my group. I was the only survivor who saw it all taking place. The soldiers were very brutal. Those who were injured but still alive and crying for help were finished off by the soldiers. I was also badly injured and I survived by pulling the intestines of my fellow comrade and covering myself. When they came to me they took my gun away just like they were doing to all the other dead bodies. The smell of human flesh, the flesh of my comrade haunts me to this day. I want to go on killing to avenge the deaths of my colleagues. Killing gives me a sense of peace. The war hardened me and I know no other life except that of being hunted and that of defending myself by killing the enemy, if I do not kill I feel redundant and my life becomes meaningless.' (Interview, 10 February 2011)
\end{abstract}

How are you able to continue with your life with such guilt feelings and haunting traumatic experiences of war?

In response to the second question, all the interviewees explained they have not been socialised into civilian life after the war. They are haunted by guilt feelings over atrocities committed during the war, such as killing other people. War veterans remain in war mode in their relationships at work or at community and family level. Out of the 51 interviewees 46 have been arrested at some time for domestic violence and 43 for public violence or malicious damage to property. Additionally, of the 51 interviewees 26 have been married more than once and they say they are unable to keep stable relationships. All of the 12 female interviewees have failed to get married. Those who have tried explain that they were violent to their husbands. Of the interviewees 38 suffer from alcohol abuse problems and they argue that alcohol helps them to forget war experiences. Comrade Lwazi describes the following:

'Memories of war live with you until you die. As a black person the ancestors of the people that I killed in war keep on following me. I am haunted. How do I get forgiveness for having killed so many people when the Bible says thou shall not kill? When I try to sleep, I can't because of war based nightmares. I tried to get married but I would always wake up at night screaming at the 
top of my voice because of reliving some traumatic experiences and my spouse says that I would be trying to strangle her to death. I can tell you that many of my colleagues are finding solace in violent crime where people use guns and military style movements to outpace their victims and the police. You see violent crime is very close to war. We are soldiers and what we know best is the use of the gun.' (Interview 14 March 2012)

Stephen explained, 'We lived in war zones for a long time, war became part of life. I am now longing for war' (interview 07 August 2011). Themba noted:

'I think that at times we killed innocent people especially those who were accused of being sell-outs and witches. The brutality that we used in killing these people was also horrific and each time I become sober I still hear their voices crying for mercy. There is this old man who keeps asking me why I killed him. He is always tormenting me, I feel so guilty and dirty for having killed such innocent people. I have tried to find his family to pay reparations but I have not been able to locate it.' (Interview 11 November 2012)

Simuka Sibanda summed up the realities of war veterans by emotionally saying:

\begin{abstract}
'You have to be like a lion when you go to war, the training makes you fearless and heartless, however, following every war, and soldiers should be ritually cleansed through rituals that take away the spirit of war so that the soldiers can live a normal non-violent civilian family life. If you do not cleanse them they will continue in the war mode bringing uncontrollable chaos in society. Soldiers can also be followed by the spirit of the people they killed in war seeking revenge. So it is important to appease all avenging spirits through a ritual.' (Interview 13 November 2012)
\end{abstract}

In general all the interviewees concurred that they are haunted by war experiences and they would appreciate some spiritual or psychological support to help them cope.

\section{What are your experiences of the following events in Zimbabwe: Gukurahundi, Murambatsvina, land reform and post-election disturbances in 2008?}

On the third question all interviewees noted that they were victims of the Gukurahundi and Murambatsvina. The war veterans were not keen to discuss the Gukurahundi in detail. All 51 interviewees had participated in the violent land reform programme. About this Josephine explains:

'I do not regret having participated in the violent land reform programme because I spent 9 years fighting for land. Some of us were trained to fight and kill if necessary, that is who I am and I have no regrets. To say that Zimbabwe is independent without land repossession was unjust. Whites also took land violently from the rightful owners using the segregatory land apportionment act of Rhodesia. I think whites should also have taken the initiative to give land back to the winners of the war, what were the whites still doing with the land that we fought for? I think that whites must have taken the initiative to discuss the land question within the first five to ten years of independence and the land redistribution might have taken a different complexion altogether.' (Interview 04 December 2012)

The 51 interviewees participated in the violent campaign for the re-run of the 2008 presidential election. The election campaign used the liberation war style of night vigils where combatants would teach propaganda against their enemies. Similarly the 2008 presidential run-off used propaganda and military violence against the opponents of ZANU-PF. Relating to this Ncube notes:

'The 2008 campaign brought back the experiences of war and we enjoyed it. This is what we know best, we excelled and ZANU-PF won the election. Tswangirai is not used to war so he withdrew from the battle field, he could not stand it. That was pure war but it is embarrassing we killed some innocent people. Violence is ok whilst it is still on but it makes me feel guilt afterwards when I reconsider some of the people we would have brutalised.' (Interview 16 December 2012)

\section{How are Prophets in your church helping you with your war experiences and related feelings?}

All the respondents claimed that they have been cleansed by the Prophets from the spirits of the dead that were haunting them. The participants have also received forgiveness of sins that they committed during the war. The Prophets pronounced forgiveness of transgressions whilst they were anointing them with holy oil as a sign of forgiveness by God. So their guilt feelings, nightmares and desire to be violent have been taken away by the holy anointment. They kept inviting their former colleagues in order for them to also experience relief from haunting spirits. On this question Simbabrashe noted:

'The prophet will take each one to the mountain for cleansing rituals which involves powerful prayers overnight, sharing the body and the blood of Jesus Christ for the forgiveness of sins, the miracles of exorcism of haunting spirits and anointment with holy oil for protection. Now I am very free. I am living a normal life because of the work of the prophet.' (Interview 16 December 2012)

All the participants did not expect to live normal lives without any form of cleansing after war. Concerning this Fuya Dlamini explained:

'In the Ndebele culture soldiers preparing for war are gathered in the kraal of the chief and bayashwama (use of herbs to prepare for war) enabling fighting and killing the enemy without mercy. Then one goes to war and becomes as brutal as the war requires one to be. One also experiences the traumatic loss of fellow soldiers. The killings in war are brutal especially when you have to kill someone with a knife or by beating them to death as the situation may require. This is different from killing using the gun where you do not necessarily have to see the face of your victim. In war you transform to a lion and you do not want your family to know your war character. After the war soldiers go back to the chief's kraal. The chief through spirit mediums and medicine men cleanses the surviving soldiers of all the killings and brutality committed during the war. This enabled soldiers 
to be human again to join their families as normal fathers. This has not been done to us, we have been released to our families with the shadows of people that we killed still following us. This is why most war veterans are acting in ways that society at times does not understand. But all this is now in the past for those of us who have been blessed by receiving cleansing and holy protection from the Prophets of our church.' (Interview 14 November 2012)

\section{Discussion on research findings}

Research findings have demonstrated that war veterans are suffering from feelings of being haunted by the spirits of the people whom they killed in war. The war veterans are also suffering from a hangover for war because of a lack of proper emotional demobilisation. They are also suffering from guilt feelings related to some war activities that border on transgressions against one's core morals. The above experiences create a condition of moral injury. It seems war veterans in Mberengwa and Gwanda want to be ritually cleansed from some spirits as well as receive absolution to rid themselves of pathological guilt feelings.

Soldiers are trained to defend their country, or in the case of a war for liberation they are trained to fight for the liberation of their country. In as much as we try to be civil in talking about military establishments, it is a fact that soldiers go through training that enables them to kill the enemy without a conscience, especially where the killing of innocent people is involved. In some instances soldiers dehumanise whoever they will be killing, with the result that in actual fact they will not be killing a human being, but that with which the human being is labelled, such as cockroaches in the Rwandan genocide, dissidents in the Gukurahundi in Zimbabwe and vatengesi (sell outs or betrayers) in the war for liberation in Zimbabwe.

According to Fuya Dlamini, the traditional Ndebele understanding of soldiering is that the concept of $u b u n t u$ (Moyo 2014:208-209; Shoko 2012:96; Shoko, J. 2013) is shelved when soldiers go to war. Ubuntu is being humane in the sense of being different from animals. Ubuntu is built around proverbs and taboos that haunt the conscience once disobeyed. For example:

- I gazi lomuntu liyakhuluma [If you kill a person, even in private, their blood speaks for them from the soil to expose and torment you].

- Abaphansi bayazilwela futhi bala mandla kulabaphilayo [The dead fight for themselves and they are more powerful than the living].

- Ongela mandla ulwelwa ngabaphansi [The dead can fight for the powerless].

- Umcabango ungathula kodwa inhliziyo ayikutholi ukuphumula [You may block yourself from thinking about having killed a person but your heart will never find peace].

- Inhliziyo enecala ayikutholi ukuphumula [A guilty heart [conscience] does not find peace/rest].

- Igazi lomuntu livusa uzimu emndenini [A murdered person's blood avenges for itself].
- Kuyazila ukuhlangana lomndeni enva kokuchitha igazi ungakahlanjululwa ngoba uletha lokho kufa emndenini [It is a taboo to join your family after committing murder without being cleansed because you will bringing death to your family].

- Obone isidumbu kafanele ahlangane labantu engagezwanga umnyama [one who has seen or touched a corpse should not relate to others before being cleansed].

Soldiers are dehumanised through their training, resulting in their ability to commit inhuman activities against other human beings. This applies to both a just and an unjust war, soldiers are trained to fight, and at most to eliminate the enemy, and this goes against the concept of ubuntu which seeks to preserve human life. People in war mode cannot be valuable or integrated into a peaceful society unless they are cleansed and demilitarised through authentic, socially acceptable rituals for moral repair.

The dehumanised soldiers work well during the war, but it becomes a challenge after the war or deliberate violence or violation of human rights, how to take away the behaviour meant for war. How do we help soldiers to be conscious of the value of human life after having been successfully trained to kill? What kind of debriefing should soldiers undergo to enable them to abandon the war mode?

As noted earlier, when soldiers are trained for war their conscience is violated, as observed by Keizer Herman, a retired colonel and chaplain in the army of the United States of America. Herman was interviewed by Brock and Lettini about violation of one's conscience. His response was that 'to violate your conscience is to commit moral suicide' (Herman in Brock \& Lettini 2012:xi). Brock and Lettini (2012:xii) go on to argue that 'The journey home to peace is perilous after war.' Brock and Lettini in their book Soul Repair: Recovering from moral injury after war discovered after interviewing several American veterans of the wars in Vietnam and Iraq that the life of a war veteran is usually lonely and full of memories of war that cannot be discussed with civilians. The stories describe psycho-emotional wounds of war based on violent, horrible experiences that violate core socially moral beliefs. 'The stories reveal the life long struggle of veterans to live with its scars, the impact on their families is enormous' (Brock \& Lettini 2012:xiii). This is evidence that there is need for debriefing after the war so that these experiences are cleansed from veterans' intrinsic moral fibre, to enable them to live a life free of the disturbing, lively and traumatic experiences of war, if possible.

This research has shown that war veterans are violent and they use available circumstances as an outlet for their hunger for war. Brock and Lettini (2012) associate this kind of behaviour to memories of war that society has neglected to respond to in a meaningful manner. They proceed to explain:

Moral injury results when soldiers violate their core moral beliefs, and in evaluating their behaviour negatively, they feel they no longer live in a reliable, meaningful world and can no 
longer be regarded as decent human beings. They may feel this even if what they did was warranted and unavoidable. Killing, torturing prisoners, abusing dead bodies, or failing to prevent such acts can elicit moral injury ... seeing someone else violate core moral values or feeling betrayed by persons in authority can also lead to a loss of meaning and faith. It can even emerge from witnessing a friend get killed and feeling survivor guilt. In experiencing a moral conflict, soldiers may see themselves as worthless; they may decide no one can be trusted and isolate themselves from others; and they abandon the values and beliefs that gave their lives meaning and guided their moral choices. (p. xv)

The irony is that military systems recruit people who would have been groomed by society, and at times also groomed by religious groups which espouse certain moral values such as ubuntu. For military training to be a success, it redefines or erases some of these socially learned values such as the Christian statement 'thou shall not kill'. Brock and Lettini (2012:xvii) observe that 'People in the military often understand the principles of just war and international standards better than members of the religious and philosophical traditions that espouse them.' However, participating in a just war does not take away the trauma or moral injury as a result of the violence that goes with any war. So despite the justification of the war, war continues to kill the moral fibre of a soldier.

In military settings where a 'command' is not questioned, soldiers are commanded, in all wars, to fight 'regardless of their moral evaluations, which can create profound inner conflicts for them' (Brock \& Lettini 2012:xvii). Soldiers interviewed by Brock and Lettini (2012) identified that

the actual conditions of war are morally anguishing. As every veteran of combat knows, the ideal of war service, the glamour of its heroics, and the training for killing fail to prepare warriors for its true horrors and moral atrocities. (p. xviii)

Hence the argument that the suffering of moral injuries through memories of war is based on the deeper humanity of soldiers.

Brock and Lettini (2012) are of the view that the moral and psycho-social challenges faced by veterans of war haunt society where these veterans live. 'In the bodies and souls of those who experience combat, war always comes home to haunt us. Veterans' families and communities, especially, carry these burdens' (Brock \& Lettini 2012:xvii).

In the African worldview, to be humane after war experiences one needs to go back to the chief's kraal to be cleansed of the evils of war (Interview 13 November 2012). Simuka Sibanda explained:

'A soldier coming from war despite having been cleansed by the medicine $\mathrm{man}^{4}$ and the spirit mediums of the chief cannot be allowed to touch his children or family members before a family

4.It is a medicine man and the soldier in this case, both of whom are male, because at that time women did not participate in war. They could only be victims of war, if it that time women did not participate in war. The
so happens that their community is attacked. medicine man and family spirit mediums cleanse him again. This is done so that he cannot bring to his family the foreign spirits from the people that he might have killed in war. The family has to make sure that they cleanse him.' (Interview 13 November 2012)

Similarly, Zimbabwe has been in war mode since the 1960s and the soldiers who participated in the different violent episodes are yet to be cleansed of the burdens of war.

\section{Moral repair for war veterans}

The responses and narratives of war veterans show that there is need for their moral repair. Moral repair can result in reduced violence and the possibility of a meaningful life for the war veterans. War veterans know that they are not well because of war trauma and that they need healing. This knowledge alone can be used as an excuse for improper behaviour as they might claim that they are stuck in the war mode.

The interviewees in this research showed that traumatic experiences keep on replaying like a video in their minds, such that they relive the experience which they end up soothing by indulging in violence. Some interviewees said that they relive the traumatic war experiences through nightmares. According to Motsi and Masango (2012) these mental videos and nightmares are

intrusions i.e. a flood of memories and images. Traumatic memory is perceived as a still frame and a mental picture. This shot is a living colour which stands stark in one's memory and is filled with intensity of emotions. (p. 3)

These intrusions can be removed through contextually relevant religious rituals. 'Therefore, a community-based and culturally sensitive approach is needed in dealing with traumatised people' (Motsi \& Masango 2012:2). The government should be able to sponsor national rituals as well as family rituals for all the war veterans in order to cut the continuing cycle of violence, based on the fact that war veterans remain in war mode.

In the case of those who feel that the people whom they killed in war continue to follow them, denying them any rest, rituals can be used to relieve the war veterans of such images by using spiritual healing or church based rituals. Amongst the Shona they can also perform rituals to stop the spirit of the dead person from tormenting the living. If the victim was innocent then the war veteran should be assisted to make a confession to the family of the deceased and pay damages if need be. The family of the deceased will then pacify the spirit of the dead person and allow the living to be freed from intrusions. In some cases the war veterans will have to travel to the grave of the deceased to confess their actions and ask for forgiveness, and then pay some respect to the spirit of the dead asking it not to haunt the living. If the family of the deceased is not known then the war veteran will pay compensation to the grave of the deceased. The African based rituals are a form of reconciliation between the dead 
and the perpetrator, as well as the family of the deceased where possible.

Killing another human being can result in Ingozi or Ngozi (Magezi \& Myambo 2011) destabilising the killer and the relatives of the killer. Shoko (Shoko, T. 2013:24) explains that 'ngozi [avenging spirit] is one of the most dreaded spirits in the Shona society.' This applies to both the criminal and the sanctioned military spilling of blood. War veterans who feel guilt at the possibility of having killed innocent people can be haunted by the fear of ingozi resulting in moral injury. Such war veterans require cleansing and if possible to pay reparations. Shoko (Shoko, T. 2013:24) goes on to remark, 'the traditional Shona hold the view that mushonga wengozi kuripa (cure for avenging spirit is to pay).' There is a need for religious based ritual cleansing and possible communication with the family of the deceased with the intention of paying reparations to them.

Rituals also bring about moral repair as the victim is assured that God or ancestors have heard their cry for moral repair. Moral repair does not happen where there is injustice. So for moral repair to happen the war veteran should confess to killings and pay compensation where necessary to bring about repair of injured morals.

In contemporary Zimbabwe it is common to see people afflicted by different human challenges moving from one church to another in search of spiritual healing. This concurs with Acolatse (2014:12) who observes that ' $[m]$ any people who suffer from a variety of human ills, whether of physical, psychological, relational, or spiritual origin, wander from one pastor to another seeking a spiritual cure.' Spiritual exorcisms that take a variety of forms in the name of Jesus are attractive to people who are troubled. The trend is that people move from mainline churches to charismatic and Pentecostal churches. There is also a significant movement of people from both the mainline churches and Pentecostal churches to African Initiated Churches (AICs) which seem to understand and respond better to challenges based on the African worldview. The Prophets associate the majority of the challenges faced by war veterans with spirituality. The pastoral care Ministry of the church in this case includes the performance of healing miracles through the words of the prophet. The prophet commands whatever will be haunting the person to come out in the name of Jesus (Mbedzi, 04 December 2012). Whilst the congregation sings and plays musical instruments, such as drums and jingles, the person seeking healing falls to the ground, convulses, screams and finally calms down and appears peaceful as a sign that the tormenting spirit has been exorcised. In some instances the one seeking for help is asked to narrate their story before the congregation and before God (Mbedzi, 04 December 2012). The prophet will then pronounce forgiveness of sins in the name of Jesus; in this case healing comes with being set free through the absolution of sins. Depending on revelations to the prophet some war veterans are asked to wash their feet, hands and faces with holy water from the altar table whilst the pastor prays for deliverance and cleansing. The traditional six functions of pastoral care, namely healing, guiding, sustaining (Hiltner 1958:89-174), reconciliation (Clebsch \& Jaekle 1965:56-66), nurturing (Clinebell 1966:4243) and liberation (Lester 1995:1) are a possible explanation of what attracts ex-combatants to the Prophets. The war veterans are wounded by war experiences, resulting in feelings of uselessness, emptiness, loneliness, fear, confusion and spiritual alienation resulting in a fixation in war mode. Lester (1995) explains:

When people are wounded and in need of healing, confused and in need of guidance, overwhelmed and in need of sustaining, alienated and in need of reconciliation, or trapped and in need of liberation, it should be obvious that hope and despair are the major psychological and theological dynamics. (p. 1)

Lester (1995) emphasises the pastoral role of the church when he notes:

A significant responsibility and privilege of ministry is to nurture hope and confront despair. Pastoral care and counselling are historically concerned with healing, guiding, sustaining, reconciling, and liberating. (p. 1)

The concerns of pastoral care which are inherent in the Ministry of the Prophets are attractive to the war-veterans. Prophets assure the war veterans of instant healing in the name of Jesus whilst mainline churches do not always give such assurances, as they promise healing whilst at the same time they encourage enduring in suffering and to expect relief in heaven (Stephen, interview). In the African worldview salvation is in the present and not in the future, hence the movement of war veterans to the healing Ministries of Prophets.

\section{Conclusion}

This article has demonstrated that war veterans in Zimbabwe are in need of the repair of injured morals. Ministries led by Prophets have managed to respond to the deep need for cleansing and absolution from guilt feelings. War veterans are joining the Ministries led by Prophets to receive healing from moral injury. Moral injuries can be repaired through religious based rituals that have contextual relevance to the one suffering moral injury, as shown above. The rituals can take any form as long as they subscribe to the religious convictions of the victim of moral injury. This article also confirms that the violent episodes in Zimbabwe were spearheaded by war veterans who kept on soothing their injured morals by participating in situations that re-enact the war situation. There is, therefore, a need for the healing and repair of injured morals amongst the liberation war veterans.

\section{Acknowledgements Competing interests}

The author declares that he has no financial or personal relationships which may have inappropriately influenced him in writing this article. 


\section{References}

Acolatse, E.E., 2014, For freedom or bondage?: A critique of African pastoral practices, Wm. B. Eerdmans Publishing Co., Grand Rapids, MI.

Alden, C., 2002, 'Making old soldiers fade away: Lessons from the reintegration of demobilized soldiers in Mozambique', Security Dialogue 33(3), 341-356. http:// dx.doi.org/10.1177/0967010602033003008

Alexander, J. \& Tendi, B.M., 2008, 'A tale of two elections: Zimbabwe at the polls in 2008', Concerned African Scholars Bulletin, No. 80, Oxford University, Oxford.

Amadiume, I. \& An-Na'im, A., 2000, The politics of memory - Truth, healing \& social justice, Zed Books, London.

Banana, C.S. (ed.), 1989, Turmoil and tenacity: Zimbabwe 1980-1990, College Press, Harare.

Bernard, G., 2005, Morality: Its nature and justification, rev. edn., Oxford University Press, New York, NY.

Bhebe, N., 1999, The ZAPU and ZANU guerrilla warfare and the Evangelical Lutheran Church in Zimbabwe, Mambo Press, Gweru.

Bhebe, N. \& Ranger, T.O., 1996, Society in Zimbabwe's liberation war, James Currey, Oxford.

Bhebe, N. \& Ranger, T. (eds.), 2001, The historical dimensions of democracy and human rights in Zimbabwe: Pre-colonial and colonial legacies-volume one, University of Zimbabwe Publications, Harare.

Bhebe, N. \& Ranger, T.O. (eds.), 2003, Nationalism, democracy and human rights, Colonial and Post-Colonial Legacies, vol. 2, University of Zimbabwe, Harare.

Blair, D., 2002, Degrees in violence: Robert Mugabe and the struggle for power in Zimbabwe, Continuum, London/New York, NY.

Braganca, A. \& Wallerstein, I., 1982, The African liberation reader, vol. 3, The strategy of Liberation, pp. 12-13, Zed Press, London.

Brock, R.N. \& Lettini, G., 2012, Soul repair: Recovering from moral injury after war Beacon Press, Boston, MA.

Browne, K., 2005, 'Snowball sampling: Using social networks to research nonheterosexual women', International Journal of Social Research Methodology 8 (1) 47-60. http://dx.doi.org/10.1080/1364557032000081663

Buffel, O.A., 2004, 'Deliver us from individualism and clericalism: Liberating pastoral care from Western individualism and clericalism', Practical Theology in Southern Africa 19 (2), 37-51.

Catholic Commission for Justice and Peace (CCJP) \& The Legal Resources Foundation 1997, Breaking the silence, building true peace: A report on the disturbances in Matabeleland and the Midlands, 1980 to 1988, viewed 15 October 2014, from http://www.zwnews.com/BreakingTheSilence1.pdf

Chitiyo, T.K., 2000, 'Land, Violence and Compensation: Reconceptualising Zimbabwe's Land and War Veterans in Zimbabwe', Journal of African Conflict and Development $1(1), 9-32$.

Chitiyo, K., 2004, 'Land, Violence and Compensation: Reconceptualising Zimbabwe's Land \& War Veteran's Debate', in P. Batchelor \& K. Kees (eds.), Demilitarisation and Peace-Building in Southern Africa, vol. 2, pp. 46-73, Ashgate, Aldershot.

Chung, F.K., 2006, Re-living the second Chimurenga: Memories from Zimbabwe's liberation struggle, Nordiska Afrikainstitutet, Stockholm.

Clebsch, W.A. \& Jaekle, C.R., 1965, Pastoral care in historical perspective, Jason Aronson, New York, NY.

Clinebell, H., 1966, Basic types of pastoral care and counseling: Resources for the Ministry of healing and growth, Abingdon Press, Nashville, NY.

Cohen, L. \& Manion, L., 1994, Research methods in education, 4th edn., Routledge, London and New York, NY.

Felsman, C., 2005, (JOC) keying for power - The joint operations command, viewed 22 November 2014, from http://www.idasa.org/our_products/resources/output/ joc_keying_for_power_the_joint/

Gerkin, C.V., 1984, The living human document: Revisioning pastoral counseling in a hermeneutical mode, Abingdon, Nashville, TN.

Gonda, V., 2013, Zimbabwe: War veterans leader threatens widespread violence, SW Radio, viewed 15 November 2014, from http://allafrica.com/stories/201304130091. $\mathrm{html}$

Hill, G., 2003, The battle for Zimbabwe: The final countdown, Zebra Press, Cape Town.

Hiltner, S., 1958, Preface to pastoral theology, Abington, Nashville, TN.

Hove, M. \& Mutanda, D., 2014, 'Revisiting the welfare of war veterans in Zimbabwe', Scholars Journal of Arts, Humanities and Social Sciences 2(1), 116-128.

Human Rights Watch, 2008, 'Our hands are tied': Erosion of the rule of law in Zimbabwe, Human Rights Watch, New York, NY.

Independent Catholic News, 2011, "Zimbabwe "war veterans" break up church meeting', viewed 16 February 2015, from http://www.indcatholicnews.com/ meeting', viewed 16 Februar
news.php?viewStory $=6554$

Jocelyn, A. \& Joan, M., 1999, 'Representing violence in Matebeleland Zimbabwe: Press and Internet Debates', University of Chicago Press, Chicago, in S.J.N. Ndlovu-Gatsheni (ed.), Putting people first - From regime security to human security: A quest for social peace in Zimbabwe, 1980-2002, Press and Internet Debates, Zimbabwe, in A.G. Nhema, 2003 (ed.). The Quest for Peace in Africa: Debates, Zimbabwe, in A.G. Nhema, 2003 (ed.), The Quest for Peace in Africa:
Transformations, Democracy and Public Policy, (International Books and Transformations, Democracy and Public Policy, (International Books and
Organisation for Social Science Research in Eastern and Southern Africa [OSSREA], Amsterdam and Addis Ababa, 2003), pp. 297-322.
Johnson, P. \& Martin, D., 1981, The struggle for Zimbabwe: The Chimurenga war, Monthly Review Press, No. 73.

Kingma, K. (ed.), 2000, Demobilisation in Sub-Saharan Africa: The development and security impacts, Macmillan Press, London.

Kriger, N., 1995, 'The politics of creating heroes: The search for political legitimacy and national identity', in N. Bhebe \& T. Ranger (eds.), Soldiers in Zimbabwe's liberation war, James Currey, London.

Kriger, N., 2003, Guerrilla warfare in post war Zimbabwe: Symbolic and violent politics, 1980-87, Cambridge University Press, Cambridge.

Lan, D.J., 1985, Guns \& rain: Guerrillas and spirit mediums in Zimbabwe, James Currey, London.

Lester, A.D., 1995, Hope in pastoral care and counselling, Westminister/John Knox, Louisville, $\mathrm{KY}$.

Louw, D.J., 1995, 'Pastoral care for the person with aids in an African context', Praktiese Teologie in Suid Afrika 10(1), 29-44.

Louw, D.J., 2013, 'Cura vitae: The hermeneutics of spiritual healing and the beautification of life', Scriptura 112(1), 1-16. http://dx.doi.org/10.7833/ $112-0-60$

Magezi, V. \& Myambo, T., 2011, 'Pastoral challenges and responses to fear of avenging spirits (ngozi) in Africa: A Biblical evaluation and response - a case of the Shona people', Die Skriflig 45(2), 161-187.

Makumbe, J., 2003, 'ZANU PF: A party in transition', in R. Conwell (ed.), Zimbabwe's turmoil: Problems and prospects, Institute of Security Studies, Pretoria.

Martin, D., 1981, The struggle for Zimbabwe: The Chimurenga war, Zimbabwe Publishing Company, Harare.

Masunungure, E. \& Bratton, M., 2008, 'Zimbabwe's long agony', Journal of Democracy 19(4), 41-55.

McGregor, J. \& Jocelyn, A., 2004, 'War stories: Guerrilla narratives of Zimbabwe's liberation war', History Workshop Journal 57(1), 79-100.

Moorcraft, P.L. \& McLaughlin, P., 1981, The Rhodesian war: A military history, Stackpole Books, Mechanicsburg.

Motsi, R.G. \& Masango, M.J., 2012, 'Redefining trauma in an African context: A challenge to pastoral care', HTS Teologiese Studies/Theological Studies 68(1), 8 pages. http://dx.doi.org/10.4102/hts.v68i1.955

Moyo, H., 2014, March, 'Dual Observances of African Traditional Religion and Christianity: Some Implications for Pastoral Care in the Pluralistic Religious Worldview of the Ndebele People of Matabo in Zimbabwe', Journal of Theology for Southern Africa, 148, 115-132.

Msomi, V.V., 2008, Ubuntu contextual African pastoral care and counselling, CB Powell Bible Centre, UNISA, Pretoria.

Murungu, S., 2004, 'Mbuya Nehanda Gandangakadzi Guru reZimbabwe', in Zambuko Projects Unlimited, viewed 16 November 2014, from http://www. zambuko.com

'Political Violence and the war veterans in independent Zimbabwe', 2011, The Zimbabwean, 16 June 2011, p. 4

Preston, M., 2004, 'Stalemate and the termination of civil war: Rhodesia reassessed', Journal of Peace Research 41(1), 65-83. http://dx.doi.org/10.1177/00223433040 40050

Ranger, T., 1992, 'Afterword: War, violence and healing in Zimbabwe', Journal of Southern African Studies 18(3), 698-707. http://dx.doi.org/10.1080/03057079208 708332

Salganik, M.J. \& Heckathorn, D.D., 2004, 'Sampling and estimation in hidden populations using respondent-driven sampling', Sociological Methodology 34(1), 193-239.

Shay, J., 2010, Odysseus in America: Combat trauma and the trials of homecoming, Scribner, New York, NY

Shira, M. \& Litz, B., 2012, 'Moral injury in veterans of war', Posttraumatic Stress Disorder Research Quarterly: Advancing Science and Promoting Understanding of Traumatic Stress 23(1), 1-6.

Shoko, J., 2013, 'Zimbabwe war veterans demand compensation', The Africa Report, 20 February 2013, 18-56, viewed 04 July 2014, from http://www. theafricareport.com/Southern-Africa/zimbabwe-war-veterans-demandcompensation.html

Shoko, T., 2006, "'My bones shall rise again": War veterans, spirits and land reform in Zimbabwe', ASC Working Paper No. 68, African Studies Centre, Leiden.

Shoko, T., 2007, Karanga indigenous religion in Zimbabwe: Health and well-being, Ashgate Publishing Company, Hampshire/Burlington.

Shoko, T., 2012, 'Karanga men, culture, and HIV in Zimbabwe', in E. Chitando \& S Chirongoma (eds.), Redemptive masculinities: Men, HIV and religion, The World Council of Churches Publications, Geneva.

Shoko, T., 2013, 'Healing in African traditional religion: Examining the implications for HIV within the context of Zimbabwe', in E. Chitando \& C. Klagba (eds.), In the name of Jesus: healing in the age of HIV, The World Council of Churches Publications, Geneva.

Tshuma, T., 2006, 'Conflict in Matabeleland and Midlands provinces: A study of evolving power struggles and the creation, demise of super ZAPU (1980-84)', unpublished honours dissertation, University of Zimbabwe.

Tungamirai, J., 1995, 'Recruitment to ZANLA: Building up a war machine', in N. Bhebe \& T. Ranger (eds.), Soldiers in Zimbabwe's liberation war, pp. 36-47, James Currey, London. 
Van der Ven, J.A., 1993, Practical theology: An empirical approach, Kok Pharos, Kampen. Wallace, G. \& Walker, A.D.M. (eds.), 1970, The definition of morality, Methuen, London.

Ward, E., 2001, 'The contribution of clinical pastoral education to pastoral ministry in South Africa', PhD dissertation, University of Natal.
Zimbabwe Human Rights Association, 1982, Choosing the path to peace and development: Coming to terms with the violations of the 1982-1987 Conflict in Matabeleland and Midlands provinces, p. 1, Zimbabwe Human Rights Association, Harare.

Zimbabwe Institute Report, 2008, Zimbabwe Institute: Harare, and Human Rights Watch, p. 16, Human Rights Watch, Harare. 